University of Nebraska - Lincoln

DigitalCommons@University of Nebraska - Lincoln

Agronomy \& Horticulture -- Faculty Publications

Agronomy and Horticulture Department

7-1969

\title{
Animal Performance on Crested Wheatgrass pastures During May and June, Fort Rock, Oregon
}

D. W. Hedrick

W. M. Moser

A. L. Steninger

R. A. Long

USDA Forest Service, ralong@uidaho.edu

Follow this and additional works at: https://digitalcommons.unl.edu/agronomyfacpub

Part of the Plant Sciences Commons

Hedrick, D. W.; Moser, W. M.; Steninger, A. L.; and Long, R. A., "Animal Performance on Crested Wheatgrass pastures During May and June, Fort Rock, Oregon" (1969). Agronomy \& Horticulture -- Faculty

Publications. 350.

https://digitalcommons.unl.edu/agronomyfacpub/350

This Article is brought to you for free and open access by the Agronomy and Horticulture Department at DigitalCommons@University of Nebraska - Lincoln. It has been accepted for inclusion in Agronomy \& Horticulture -Faculty Publications by an authorized administrator of DigitalCommons@University of Nebraska - Lincoln. 


\section{Animal Performance on Crested Wheatgrass Pastures During May and June, Fort Rock, Oregon ${ }^{1}$}

\author{
D. W. HEDRICK, W. M. MOSER, A. L. STENINGER, \\ R. A. LONG \\ Professor of Range Management, Oregon State \\ University, Corvallis; County Agent, Lakeview; \\ Range Consulant, formerly Area Manager, \\ $B L M$, Lakeview, and \\ retired rancher, Fort Rock, Oregon.
}

\section{Highlight}

Average animal performance data of $1.5 \mathrm{lb} /$ animal daily gain, two calendar months of grazing, and $20 \mathrm{lb} /$ acre gain were obtained from 5 years of using crested wheatgrass under a 2-crop (May) and 1-crop (June) system of grazing. Regrowth was obtained on early use (2-crop) pastures in only 2 out of the 5 years. Extension of results to users was hastened by involving ranchers, a county agent, and a federal agency manager in the study.

Improvement programs on the Western Range have resulted in significant acreages of deteriorated native forages being replaced by introduced species, chiefly crested wheatgrass (Agropyron desertorum (Fisch.) Schult.). Comprehensive studies on these seedings have been made in Utah (Frischknecht and Harris, 1968), New Mexico (Springfield, 1963), and Idaho (Sharp, 1966). These grazing experiments have included evaluation of both vegetation and cattle responses based on intensity and season of grazing. Little attention, however, has been paid to these influences in relation to stem morphology and physiological factors as suggested by Hyder and Sneva (1963). They proposed heavy grazing for crested wheatgrass in mid-May to remove flower stalks. Regrowth from crested wheatgrass grazed thusly is from new undifferentiated buds which Hyder and Sneva called 2-crop grazing since the second crop is of vegetative tillers. Production of the second crop varies with the amount of soil moisture available for plant growth in June and July. Animals are moved to the next area in late May when crested wheatgrass heads are high in the boot, and grazing is adjusted for maximum forage and livestock production. Hyder and Sneva referred to this as 1-crop grazing. Regrowth of vegetative tillers (if any) on the 2-crop can then be grazed after maturity in late summer or fall. The type of grazing can be rotated between areas from year to year.

One of the problems facing research workers and users of new information is the gap that commonly occurs between availability of research knowl-

\footnotetext{
${ }^{1}$ Technical Paper No. 2533, Oregon Agricultural Experi ment Station. Received August 30, 1968; accepted for publication February 27, 1969.
}

edge and its application. This study was cooperatively initiated by two ranchers ( $R$. A. Long and Frank Anderson), three public agencies (BLM, USFS, SCS), and two branches of Oregon State University (research and extension). An effort was made thereby to bridge the gap or avoid the lag by involving both research and management groups in the study. During the five-year experiment, extension and land management agencies were using the area as a demonstration of opportunities available to both users and administrators to improve the flexibility of grazing crested wheatgrass. Thus, a two-fold purpose was evident: (1) Test a theoretical model developed for grazing crested wheatgrass, (2) Shorten the period between obtaining and using the information from this cooperative trial. Much of the credit for initiating and prosecuting the study goes to Mr. Rueb Long, a resident rancher, who made his services available whenever needed to coordinate the efforts of all supporting parties.

\section{Experimental Area and Procedures}

The portion of the Fort Rock Valley included in this study is characterized by a natural vegetation of big sagebrush (Artemisia tridentata) and Thurber's needlegrass (Stipa thurberiana). Currently the most abundant grass is squirreltail (Sitanion hystrix) with varying amounts of green and gray rabbitbrush (Chrysothamnus viscidiflorus, Chrysothamnus nauseosus) resulting from farming and grazing disturbances. Nearly all of the valley bottom was homesteaded during or after World War 1.

Surface soils vary in texture from sandy to sandy loam and unless protected by a vegetative cover are eroded by strong winds in February, March, and April. The B-Horizon is finer textured than the $\mathrm{A}$ and often appears as an indurated layer or pan when dry. Soil moisture becomes limiting in late spring when dry winds withdraw much of the surface moisture before soil temperatures are high enough to permit rapid plant growth.

Weather records from a site close to the experimental area indicate a 20 -year mean precipitation of about 10 inches of which about $30 \%$ falls in the growing season of March through June (Table 1). Mean minimum temperatures are below freezing until late May which further restricts growth when available moisture is adequate (Fig. 1).

Four 12-acre pastures were seeded in April, 1960, with crested wheatgrass. Seedbed preparation consisted of rotobeating big sagebrush and gray and green rabbitbrush in 1958 and spraying the rabbitbrush sprouts with 2,4-D in 1959 to avoid plowing the area and increasing its susceptibility to wind erosion.

The experimental area was grazed by horses to remove old growth in March, 1963. The first grazing with yearling heifers on 2-crop pastures was from about May 10, until May 31, 1963. The animals were then moved to 1-crop pastures where they grazed until July 5. Regrowth on the early grazed units was then used until the end of July. Grazing in subsequent years followed a similar pattern with 2-crop grazing starting in May and 1-crop in June, except that regrowth was available on 2-crop units in only two of the five years (Table 2). 
Table 1. Selected growing season weather records from Fremont official station adjacent to experimental area.

\begin{tabular}{|c|c|c|c|c|c|c|}
\hline Month & 20-year mean & 1963 & 1964 & 1965 & 1966 & 1967 \\
\hline \multicolumn{7}{|c|}{ Precipitation (inches) } \\
\hline March & 0.7 & 0.83 & 1.08 & $\mathrm{~T}$ & 0.64 & 0.85 \\
\hline April & 0.6 & 1.02 & 0.13 & 0.93 & 0.03 & 1.15 \\
\hline May & 1.1 & 1.47 & 0.10 & 0.74 & $\mathrm{~T}$ & 0.35 \\
\hline June & 1.0 & 0.77 & 1.35 & 0.76 & 0.68 & 1.49 \\
\hline \multicolumn{7}{|c|}{ Growing } \\
\hline $\begin{array}{l}\text { Annual } \\
\text { Total }\end{array}$ & 10.2 & 11.59 & $17.87^{1}$ & 11.15 & 8.88 & 8.69 \\
\hline \multicolumn{7}{|c|}{ Mean minimum temperatures $\left({ }^{\circ} \mathrm{F}\right)$} \\
\hline March & 21.7 & 23.5 & 21.3 & 17.1 & 18.7 & 19.4 \\
\hline April & 24.3 & 25.6 & 22.5 & 29.7 & 24.0 & 18.2 \\
\hline May & 29.3 & 35.2 & 27.8 & 28.9 & 31.3 & 30.6 \\
\hline June & 34.0 & 37.7 & 37.5 & 38.2 & 36.7 & 36.3 \\
\hline
\end{tabular}

1 Ten inches of this total in December.

Forage production clippings on ungrazed areas were started late in spring, usually mid-April before the start of early 2-crop grazing. They were continued (start of grazing, time of change to 1-crop and end of 1-crop, plus end of grazing on 2-crop regrowth when available) throughout the growing season. Clippings were taken at 1.5 inches stubble height approximating the grazing level of yearling heifers, weighed green in the field, dried at $105 \mathrm{C}$ for 24 hours, and ground for crude protein anaylsis.

Calculations based on these clippings and the normal growth curve provided predictions in stocking rates and length of the grazing season that were rarely more than 2 or 3 days in error (Fig. 2). Yield clippings were analyzed for crude protein to provide a rough check on the nutritional value of crested wheatgrass during the three periods of grazing (2-crop, 1-crop, and regrowth on 2-crop, if any).

The frequency of occurrence of grasses and shrubs in $1 \times$ 1-ft quadrats was determined in June, 1963, 1966, and 1968. Two or three samples of 100 quadrat placements each were taken in each pasture. The presence of a species in any quadrat was determined by the occurrence of one or more stems or shoots observed at ground level.

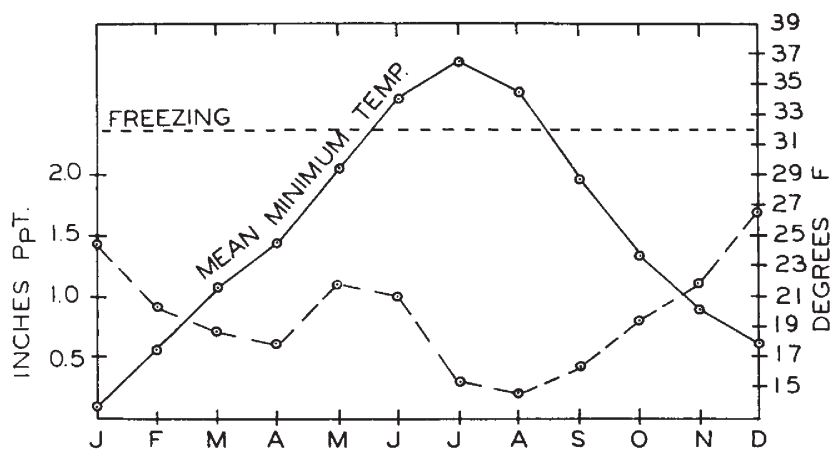

FIg. 1. Mean precipitation and minimum temperatures from Fremont station adjacent to experimental area.
Table 2. Pasture rotation used at Fort Rock

\begin{tabular}{lll}
\hline & \multicolumn{2}{c}{ Grazing system } \\
\cline { 2 - 3 } Year & 2-crop & 1-crop \\
\hline 1963 & A \& B & C \& D \\
1964 & A \& B & C \& D \\
1965 & C \& D & A \& B \\
1966 & A \& B & C \& D \\
1967 & C \& D & A \& B
\end{tabular}

$\overline{1 \text { Years in which regrowth was available for grazing after 1-crop. }}$

\section{Results and Discussion}

Stands of crested wheatgrass have been adequately maintained under this intensive type management (Table 3). Although frequencies of crested wheatgrass have declined slightly in pastures 2 and 4 , the total grass stand has remained constant when averaged over all pastures. The relatively high frequency of approximately $65 \%$ reflects the desirability of a fairly dense stand when grazing is dictated by stem morphology. The lack of precipitation in April and May, 1966, appeared to be detrimental to crested wheatgrass.

Forage production is shown in Figure 2; it was rather consistent over the years except for the low total in 1966 and in April of 1963 and 1967. Precipitation limited growth in 1966. Heavy horse grazing to remove old herbage in March 1963, undoubtedly reduced early growth in 1963. Low April temperatures delayed vegetative development in 1967.

Fig. 3 reveals two general patterns in crude protein content of crested wheatgrass in relation to intensive use. The first (1963) and last year (1967)

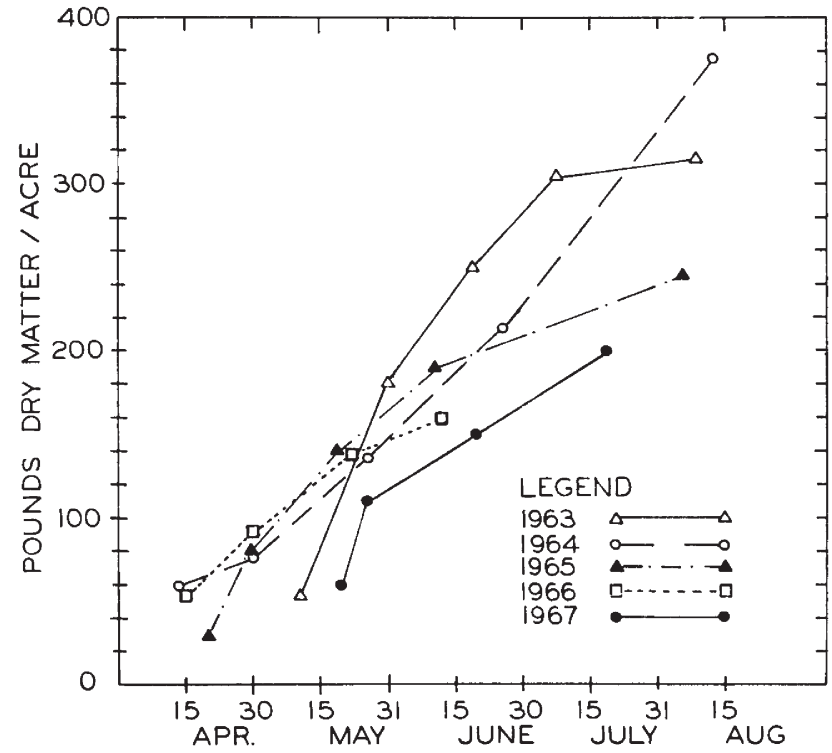

Fig, 2. Forage growth on crested wheatgrass (above 1.5 inches stubble height) during 5 years at Fort Rock. 
Table 3. Percentage frequency data for grasses and shrubs in Fort Rock grazing trial from 1963 to 1968.

\begin{tabular}{|c|c|c|c|c|c|c|c|c|c|c|c|c|}
\hline \multirow{2}{*}{$\begin{array}{c}\text { Pasture } \\
\text { no. }\end{array}$} & \multicolumn{3}{|c|}{$\begin{array}{c}\text { Crested } \\
\text { wheatgrass }\end{array}$} & \multicolumn{3}{|c|}{$\underset{\text { tail }}{\text { Squirrel- }}$} & \multicolumn{3}{|c|}{$\begin{array}{c}\text { All } \\
\text { shrubs }\end{array}$} & \multicolumn{3}{|c|}{$\begin{array}{l}\text { Total } \\
\text { grass }\end{array}$} \\
\hline & 1963 & '66 & '68 & 1963 & '66 & '68 & 1963 & '66 & '68 & 1963 & '66 & '68 \\
\hline 1 & 65 & 43 & 64 & - & 11 & 6 & 1 & 2 & 1 & 65 & 53 & 7 \\
\hline 2 & 72 & 57 & 65 & - & 7 & 2 & - & 2 & 1 & 72 & 61 & 6 \\
\hline 3 & 59 & 51 & 58 & - & 10 & 4 & - & - & 1 & 59 & 61 & 62 \\
\hline 4 & 62 & 55 & 57 & - & 13 & 9 & - & - & 2 & 62 & 68 & 6 \\
\hline
\end{tabular}

values are similar and, in contrast, the intermediate years remained higher throughout the summer period. These relatively high crude protein values in dry years help to explain why animal performance was good in spite of low herbage production. The rapid drop in protein for 1963 and 1967 was associated with good growing conditions in those years.

Animal performance varied with climatic conditions and date of turnout (Table 4). However, the average performance of $20 \mathrm{lb} /$ acre gain, $1.5 \mathrm{lb}$ /head daily, and about 2 months of grazing each year represent realistic figures in comparison with other studies. Using these averages of $20 \mathrm{lb}$ liveweight gain and $200 \mathrm{lb} /$ acre of forage, a relatively high efficiency of conversion (10:1) of forage into meat was realized.

The difficulty of obtaining uniform utilization on crested wheatgrass was evident in this study with small 12-acre pastures. Seldom was growth of all seed stalks inhibited even though heavy grazing pressure was applied in the early 2-crop grazing. Part of this difficulty can be attributed to using young animals more selective and discriminating in their foraging habits than mature cows. Grazing beginning in April tended to reduce selectivity and keep the forage more nutritious than when start of grazing was delayed to middle or late May. The

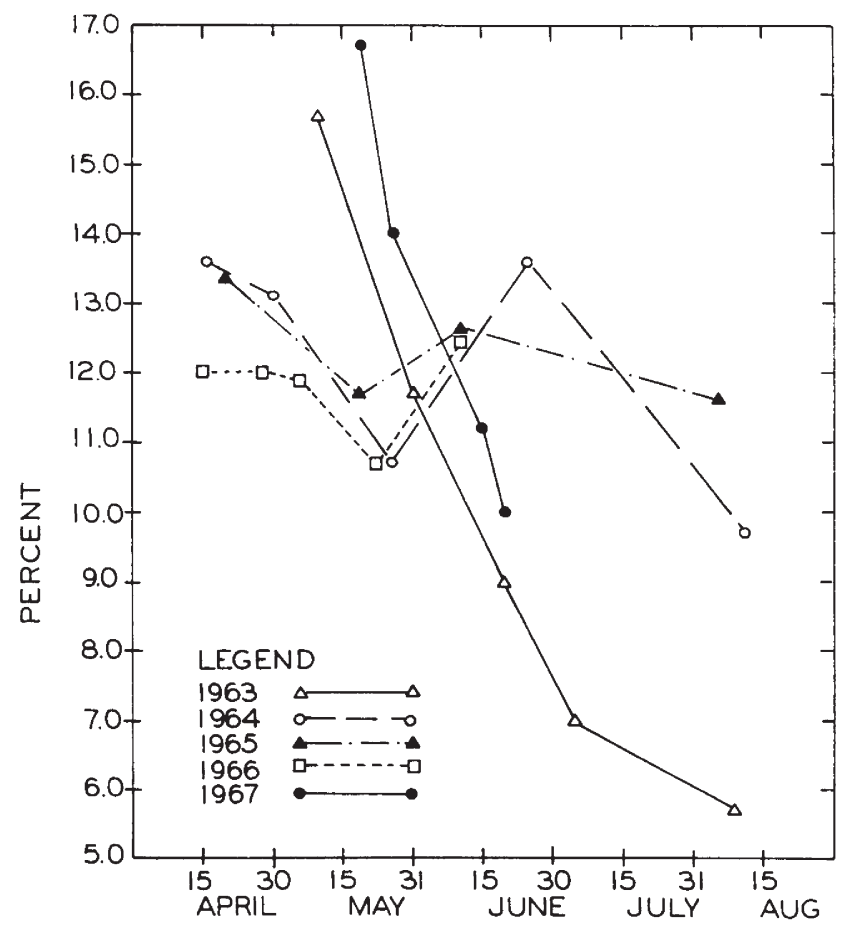

Fici. 3. Crude protein contents of crested wheatgrass grown at Fort Rock.

same results were noted in a 10 -year study in the foothills of the Steen Mountains (Hedrick, 1967).

In general, results of this study substantiate Hyder and Sneva's contention that heavy early grazing up to the boot stage suppresses seed stalk formation and results in vegetative regrowth. Perhaps the most important finding is that wolf plants can develop under intensive grazing of crested wheatgrass if the start of grazing is delayed too long in the spring. Heavy use of crested wheatgrass in May and June by 1 -crop and 2-crop grazing rotated between pastures, provides maximum benefits to adjacent native ranges.

Table 4. Animal performance data by grazing systems and years. ${ }^{1}$

\begin{tabular}{|c|c|c|c|c|c|c|c|c|c|c|c|c|c|c|c|c|}
\hline \multirow{2}{*}{$\begin{array}{l}\text { Animal gain } \\
\text { and stocking } \\
\text { rate }\end{array}$} & \multicolumn{5}{|c|}{ 2-Crop Grazing } & \multicolumn{5}{|c|}{ 1-Crop Grazing } & \multicolumn{6}{|c|}{ Average production by years } \\
\hline & 1963 & 1964 & 1965 & 1966 & 1967 & 1963 & 1964 & 1965 & 1966 & 1967 & 1963 & 1964 & 1965 & 1966 & 1967 & Avg. \\
\hline $\begin{array}{l}\text { Liveweight gain } \\
\text { lb/acre }\end{array}$ & 31 & 27 & 14 & 8 & 20 & 40 & 21 & 15 & 22 & 23 & 36 & 24 & 14 & 15 & 22 & 22 \\
\hline $\begin{array}{l}\text { Daily gain, } \\
\text { lb/animal }\end{array}$ & 1.4 & 1.6 & 0.9 & 0.8 & 1.8 & 2.3 & 1.5 & 1.4 & 2.1 & 1.5 & 1.8 & 1.5 & 1.1 & 1.5 & 1.7 & 1.5 \\
\hline $\begin{array}{l}\text { Calendar days } \\
\text { grazing }\end{array}$ & 45 & 34 & 30 & 19 & 24 & 35 & 30 & 21 & 21 & 29 & 80 & 64 & 51 & 40 & 53 & 58 \\
\hline Dates of grazing & $\begin{array}{l}5 / 10 \\
\text { to } \\
5 / 31^{2}\end{array}$ & $\begin{array}{c}4 / 22 \\
\text { to } \\
5 / 26\end{array}$ & $\begin{array}{c}4 / 28 \\
\text { to } \\
5 / 19^{2}\end{array}$ & $\begin{array}{c}5 / 5 \\
\text { to } \\
5 / 23\end{array}$ & $\begin{array}{c}5 / 26 \\
\text { to } \\
6 / 19\end{array}$ & $\begin{array}{c}5 / 31 \\
\text { to } \\
7 / 5\end{array}$ & $\begin{array}{c}5 / 26 \\
\text { to } \\
6 / 25\end{array}$ & $\begin{array}{c}5 / 19 \\
\text { to } \\
6 / 9\end{array}$ & $\begin{array}{c}5 / 23 \\
\text { to } \\
6 / 13\end{array}$ & $\begin{array}{c}6 / 19 \\
\text { to } \\
7 / 18\end{array}$ & & & & & & \\
\hline
\end{tabular}

\footnotetext{
1 Each 12-acre pasture was stocked with six yearling heifers weighing about $400 \mathrm{lb}$ at the start of grazing.
2 Final dates of grazing for two-crop system in 1963 were from July 5 to 29, and in 1965 from June 9 to 18 .
} 
Research results were provided to interested users with a minimum of delay by involving both the local County Extension Agent and the Area Manager of the Bureau of Land Management in this trial.

\section{LITERATURE CITED}

Frischknecht, Neil C., AND L. E. Harris. 1968. Grazing intensities and systems on crested wheatgrass in Central Utah: Response of vegetation and cattle. USDA Forest Serv. Tech. Bull. 1388: 1-47.
Hedrick, D. W. 1967. Managing crested wheatgrass for early spring use. J. Range Manage. 20: 53-54.

Hyder, D. N., ANd F. A. Sneva. 1963. Morphological and physiological factors affecting the grazing management of crested wheatgrass. Crop Science 3: 267-271.

SharP, LeE A. 1966. Vegetation and animal responses to grazing crested wheatgrass at three intensities and two seasons in southern Idaho. PhD Thesis, Oregon State Univ. $135 \mathrm{p}$.

Springfield, H. W. 1963. Cattle gains and plant responses from spring grazing on crested wheatgrass in northern New Mexico. USDA Prod. Res. Report No. 74: 1-46. 